\title{
Changes in the behaviour of the sole, Solea vulgaris, during cold winters, and the relation between the winter catch and sea temperatures
}

\author{
Peter M. J. Woodhead \\ Fisheries Laboratory, Lowestof, England
}

\begin{abstract}
KURZFASSUNG: Veränderungen im Verhalten der Seezunge Solea vulgaris während kalter Winter und die Beziehung zwischen Winterfang und Meertemperaturen. Während kalter Winter werden ungewöhnlich große Seezungenfänge eingebracht. Diese Tatsache hängt offenbar zusammen mit der durch das kalte Wasser verursachten Ansammlung großer Bestände in relativ kleinen Gebieten, mit der erhöhten Verwundbarkeit durch die Schleppnetzfischerei bei niedrigen Temperaturen sowie mit der längeren Anwesenheit der Seezungen in küstennahen Schleppnetzgründen. Solea vulgaris ist offenbar besonders empfindlich gegenüber niedrigen Temperaturen. Es konnte eine deutliche Beziehung zwischen Winterfangergebnissen und der Wassertemperatur nachgewiesen werden.
\end{abstract}

\section{INTRODUCTION}

During periods when temperatures fall abnormally low in the North Sea, very high catches of fish may be made in deeper areas such as the Silver Pits $\left(54^{\circ} \mathrm{O}^{\prime} \mathrm{N}\right.$ from $2^{0}$ to $3^{0} \mathrm{E}$ ); fishermen are well aware of these facts, and indeed this wellknown fishing ground was first discovered during a cold winter and owes its name to the very valuable catches of soles made there. Writing of this discovery Woon (1911) states that "the winter of 1834 was very severe and myriads of soles had been driven by the cold into the deep water of that particular part of the North Sea (Silver Pits). Very few trawlers were then at work but one of them, a Hullman, had his gear down. When the trawl was hauled it was found to be full of fish, ... the entire catch consisted of soles". During the winters of 1929 and 1947, when dead fish were reported over a wide area, there were also exceptionally large catches of fish, especially of soles (Lumby \& AtKinson 1929, Simpson 1953). This happened again during the winter of $1962 / 63$, when 2,487 tons of soles were caught in the southern North Sea (statistical regions IVB and IV C) by English trawlers between January and April, nearly a fourfold increase over the average of 656 tons during the same months for the period 1959 to 1962 (Table 1). At the same time the sole catch of the Dutch trawling fleet, fishing the same regions, increased by two and a quarter times from an average of 3,273 tons to 7,350 tons (AnON 1963a). The landings by Belgian trawlers from the 
Southern Bight (statistical region IV C only) increased even more dramatically, their catch of soles from January to March being 4,730 tons compared with 335 tons in 1962 (GIrrs 1963). The large catches made in the winter of $1962 / 63$ were particularly

Table 1

Trawl landings of soles, total for January-April from southern North Sea by English and Dutch vessels

\begin{tabular}{|cccc|}
\hline Year & $\begin{array}{c}\text { Total } \\
\text { English landing } \\
\text { (tons) }\end{array}$ & $\begin{array}{c}\text { kg per 100 hrs } \\
\text { fishing by vessels } \\
\text { landing soles }\end{array}$ & $\begin{array}{c}\text { Total } \\
\text { Dutch landing } \\
\text { (tons) }\end{array}$ \\
\hline 1959 & 561.4 & 320.0 & $2,051.7$ \\
1960 & 669.1 & 335.3 & $2,808.7$ \\
1961 & 579.3 & 309.9 & $3,451.3$ \\
1962 & 814.6 & 426.7 & $4,778.9$ \\
Mean & & & $3,272.7$ \\
$1956-62$ & 656.1 & 350.5 & $7,350.3$ \\
1963 & $2,486.8$ & $1,214.1$ & \\
\hline
\end{tabular}

outstanding since, although sole landings have been slowly increasing from the North Sea, a slight fall in catches had been expected from consideration of recruitment and of the predicted size of the North Sea sole stocks in 1963 (Anon 1963b).

This paper will consider changes in the behaviour of the sole populations during the winter, which contributed to these high catches. The soles appear to be particularly sensitive to low temperatures, and an attempt is made to relate the winter catch of soles to water temperatures in the North Sea.

\section{INCREASED VULNERABILITY OF THE FISH TO TRAWLING}

It is well established that the largest trawl catches of soles are made during the night (Boerema \& Stam 1952, Boerema 1964, Woodhead 1964a), the average number per night haul in winter being up to five times that in daylight. From aquarium observations it seems likely that soles usually lie partly buried in the sea-bed during daytime; they are then difficult to displace and may well burrow more deeply when a trawl approaches. With the onset of darkness they swim actively about over the bottom searching for food, and at this time it might be expected that they would more easily be disturbed by the footrope of a trawl net and caught (KRuuK 1963, WooDHEAD 1964b). Since large numbers of soles died in areas to the south of the Dogger Bank this winter, it was probable that many of the live fish were in an inactive, semi-torpid condition; in such circumstances it seemed unlikely that they would burrow to avoid the trawl, so that the large catches made in this area could have been partly due to this change in the vulnerability of the fish to fishing gear. If such an increase in vulnerability had occurred during the cold winter of 1963, there should have been no evidence of the normal diurnal changes in the trawl catches of soles. 
Skipper Ivan S. Down of the Lowestoft trawler "Highland Lady" made a detailed report for each trawl haul on a cruise in the area during this period, and an analysis of his report for 23 night-time and 30 day-time hauls, yielding about $3,500 \mathrm{~kg}$ of soles, gave an average of $62.2 \mathrm{~kg}$ of soles per haul by day and $62.1 \mathrm{~kg}$ by night, confirming that there were no differences between the day and night catches (WOODHEAD 1964b).

In the discussion of irregular features of the cold winter with trawler officers it was frequently stated that many cod were feeding very heavily upon soles. (It is not known whether these fish were true soles, Solea vulgaris, or a mixture of soles with the smaller solenette, $S$. lutea). Although cod which have eaten a few soles are commonly caught, these reports were unusual in that the cod stomachs were often packed full of small soles, and because so many cod were feeding heavily on soles throughout the North Sea south of the Dogger Bank. Mr. Jørgen Møller ChristenSEN informs me that in the eastern parts of the North Sea Danish fishermen had also reported that most cod had some soles in their stomachs. It is interesting that reports of unusually large numbers of cod eating soles were often made from grounds on which very few dead soles were being caught, as well as in the areas where high mortalities had occurred (WoODHEAD 1964c). These reports would suggest that the soles were exceptionally accessible to predation, again probably because they were not burying into the sand in their normal manner.

BoEREMA (1964) has analysed in some detail the diurnal pattern of trawl capture of soles for the winter months of January and February. From his results I have calculated that if soles were caught throughout the day at the same rate as during their night-time maximum, the total catch for the 24 hours would be increased by $60 \%-80 \%$. If there were no diurnal changes in sole catches during the present winter, an increase in total catch of up to $80 \%$ might therefore have been expected, but this was much less than actually occurred. Of course, it was possible that the fish were also easier to capture at night as well as by day.

\section{CONCENTRATION OF FISH BY COLD WATER}

It seems probable that during the winter of $1962 / 63$ soles avoided the cold water masses extending from the shallower coastal areas, and that this behaviour produced a high density of fish in a smaller area than in normal winters, thus contributing to the large catches. Consideration of the distribution of sole catches made by English trawlers showed that the largest numbers were caught at the edges of the colder areas, few soles being caught within the coldest waters. The research vessel surveys (WOODHEAD 1964c) made in these colder regions also found few live soles.

For the purposes of population analysis, the southern North Sea (statistical regions IV B and IVC) is routinely subdivided in to a number of rectangles approximately 30 miles square (Fig. 1). During the winter months of January to April it is usual for the largest catches of soles to be made in the eastern part of the North Sea, between the Danish coast and $5^{\circ} \mathrm{E}$ (rectangles $\mathrm{K}, \mathrm{L}$ and $\mathrm{M}, 7,8$ and 9; Fig. 1). In the winter of 1963 the catch of soles in this eastern area did not show the increase which 
Table 2

Average catch of Soles ( $\mathrm{kg}$ per 100 hours fishing by vessels catching soles)

\begin{tabular}{|c|c|c|c|c|}
\hline Year & January & February & March & April \\
\hline \multicolumn{5}{|c|}{ Western Area (Rectangles $E, F, G, 6 \& 7)$} \\
\hline 1959 & 416.6 & 320.0 & 274.3 & 213.4 \\
\hline 1960 & 345.4 & 274.3 & 238.8 & 152.4 \\
\hline 1961 & 294.6 & 299.7 & 294.6 & 127.0 \\
\hline 1962 & 436.9 & 335.3 & 309.9 & 248.9 \\
\hline \multicolumn{5}{|l|}{ Mean } \\
\hline $1959-62$ & 375.9 & 304.8 & 279.4 & 182.9 \\
\hline 1963 & $1,686.6$ & $4,053.8$ & $3,373.1$ & $2,352.0$ \\
\hline \multicolumn{5}{|c|}{ Eastern Area (Rectangles $K, L, M, 7,8$ \& 9) } \\
\hline 1959 & 610.0 & 345.4 & 518.2 & 690.9 \\
\hline 1960 & 751.8 & 701.0 & 660.4 & 309.9 \\
\hline 1961 & 569.0 & 528.3 & 624.8 & - \\
\hline 1962 & 833.1 & 756.9 & 797.6 & 447.0 \\
\hline \multicolumn{5}{|l|}{ Mean } \\
\hline $1959-62$ & 690.9 & 584.2 & 650.2 & 482.6 \\
\hline 1963 & 624.8 & 533.4 & 528.3 & - \\
\hline
\end{tabular}

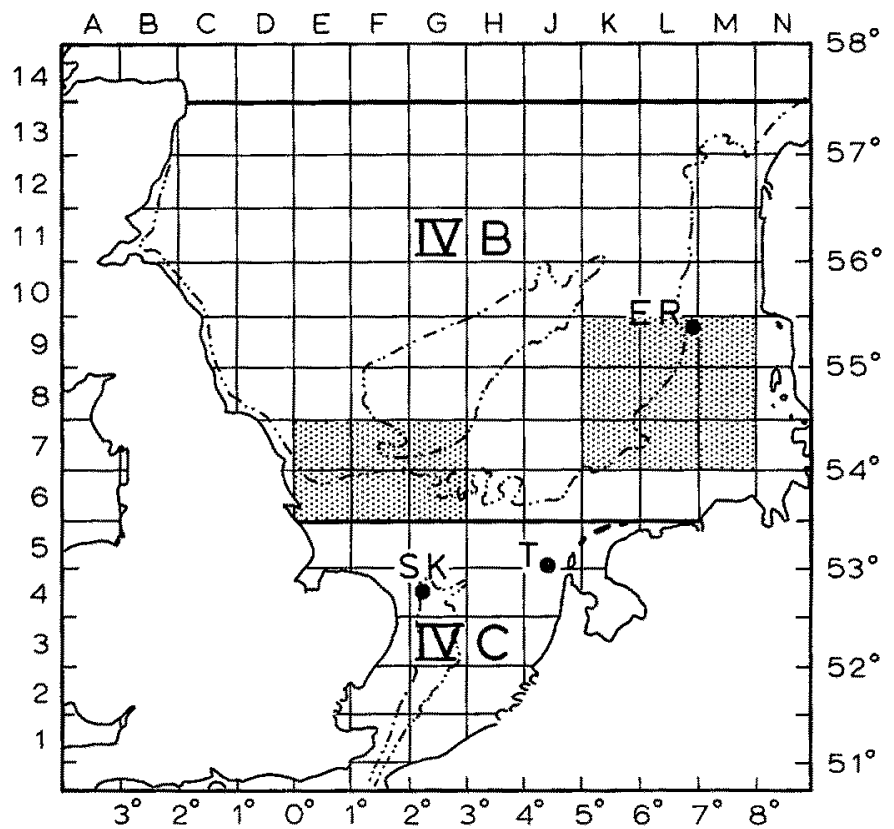

Fig. 1: Statistical regions IVB and IVC, showing the "eastern" and "western" areas, and the positions of "E. R.", Texel, and Smith's Knoll lightships 
occurred in the North Sea in general; indeed, the catches were a little lower than the average for the four previous winters (Table 2). Since most of the eastern area was covered by cold water, the average catch there might have been expected to increase, in view of the increased vulnerability to trawling of soles at low temperatures. As this did not happen it was concluded that most of the soles had left the eastern part of the North Sea.

The largest English catches were made in the western North Sea between $3^{\circ} \mathrm{E}$ and the English Yorkshire coast (rectangles E, F and G, 6 and 7; Fig. 1). During 1963, the average January catches were more than four times larger than usual in this western area, and in February, March and April they had increased to twelve times the average for the previous four years (Table 2). It is unlikely that this spectacular increase could be accounted for entirely by the greater vulnerability of the fish to trawling and it seems that soles had immigrated into the area, probably from the colder, shallow continental coastal areas to the east and south-east, and from English banks to the south. During the cold winter of 1929, Lumby \& Atkinson (1929) showed a similar increase in average catches on the western fishing grounds, which was accompanied by a fall in the average catch of soles in the east, although the changes in 1929 were much smaller than occurred in 1963.

Ginis (1963) has recently discussed the very high catches of soles made by Belgian trawlers in the Southern Bight (statistical region IVC) during the winter of $1962 / 63$. It was apparent from his figures that most of these fish were caught in the deeper parts of the Southern Bight. Gilis also concluded that many of the soles had been forced to move out of the coastal regions by the rapid cooling of the waters in these shallow areas.

\section{RECAPTURES OF TAGGED SOLES}

During March and April, in 1959 and 1960, Mr. A. R. Margetts and Mr. T. Williams of this laboratory tagged 2,558 soles off the Danish and German coasts; that is, in the general "eastern area" discussed in the previous section. It is therefore interesting to consider the distribution of recaptures of these fish during the winter of $1962 / 63$ in comparison with the previous "warm" winters. For this purpose the distribution of the fish during the first quarter, January to March, of each year (excluding recaptures during the year when the fish were tagged) has been presented as the numbers of tagged fish recaptured in each statistical rectangle for all the years up to, and including, 1962 (Fig. 2). Unfortunately, by 1963 many of these tagged soles had already been recaptured, but the positions of the fifteen fish caught during the winter of $1962 / 63$ have been plotted on the same diagram and it is apparent that they were distributed at the western edge of the previous winter distributions. The 1963 recaptures mainly lie just outside the position of the $2^{\circ} \mathrm{C}$ sea surface isotherm in March (ELLETT 1963). However, only one of these fish was caught far to the west of any previous winter recaptures, and none were taken in the areas of the highest English trawler catches.

Although there was not a large number of recaptures in the winter of 1963 from 
these sole tagging experiments, the results would seem to show that the soles which spawn in the Danish coastal waters, and probably also the stock of soles spawning in the German Bight, did not contribute largely to the English trawl catches. Many of these fish were recaptured near the areas of the highest reported mortalities (WooDHEAD 1964c) and these stocks may have suffered more heavily in this respect than the

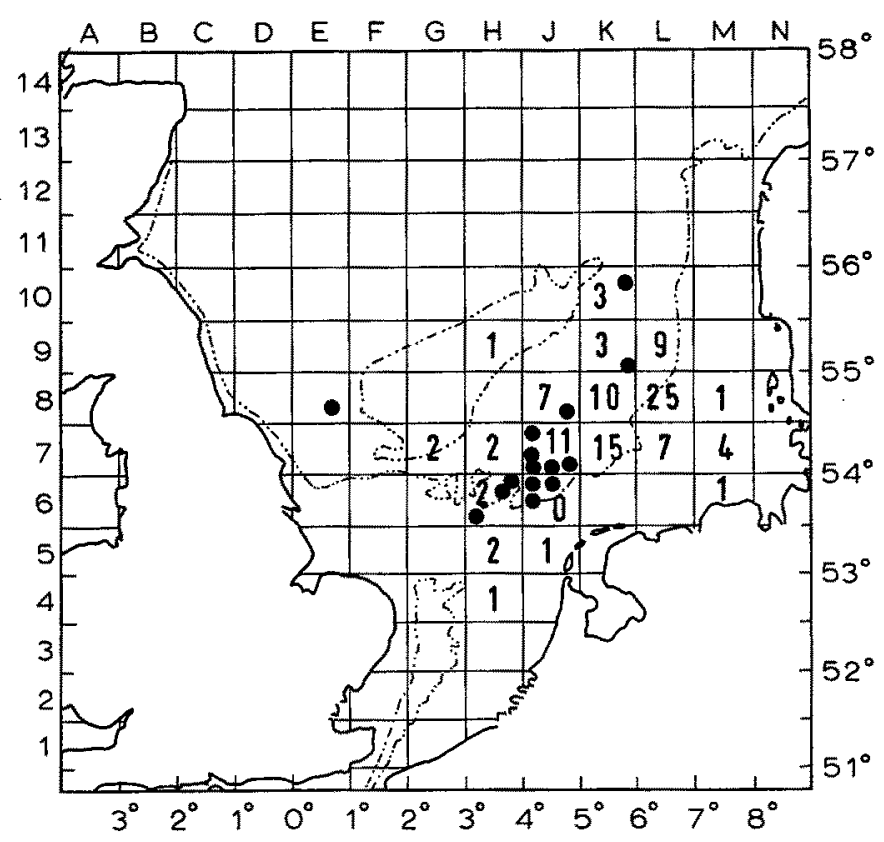

Fig. 2: Recapture pattern of tagged soles in January-March 1963 (denoted by circles), compared with the distribution of recaptures in previous winters (total numbers for 1960-1962)

populations with a more westerly distribution. It is assumed that the "western areas" of high catches off the English Yorkshire coast contained not only local soles, but also many fish forced out from the Dutch coastal grounds and from the inshore English grounds by the cold water masses.

\section{SPRING INSHORE MIGRATION}

A general inshore migration of soles occurs in spring, at least amongst the large sole stocks from the eastern side of the North Sea (Report of the Sole Working Group 1962). Møller Christensen (1962) has described a relationship between the sea temperatures and the dates of the beginning of the fishery for the soles which spawn in the Danish inshore areas; when sea temperatures are low the arrival of the soles on the coast may be delayed by up to four weeks. He informed me that in the spring of 1963 the Danish inshore fishery was later and did not begin until the end of May, instead of mid-April. This would probably contribute to increased trawler 
catches, since the soles would presumably remain available for capture on the offshore trawling grounds for a longer time.

Of the soles tagged by Mr. Marget'Ts and Mr. Williams, the seven recaptures in the second quarter of 1963, April to June, were made well to the west of their previous distribution (Fig. 3). Another three soles were recaptured by Dutch trawlers during April, but no data were given about the position of recapture; however, it

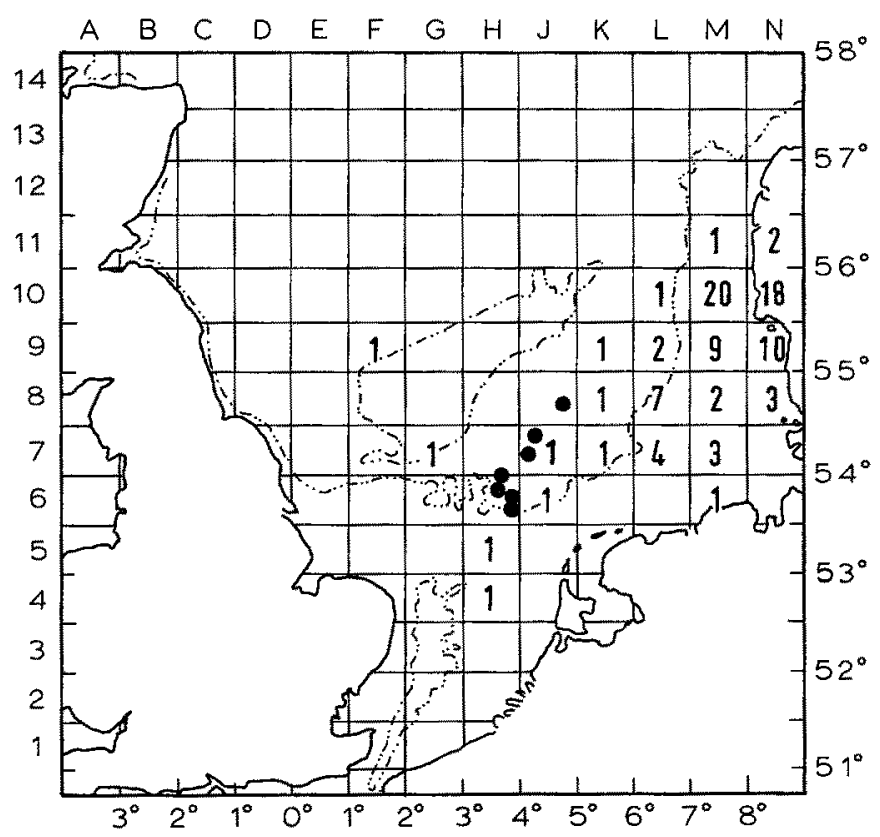

Fig. 3: Recapture pattern of tagged soles in April-June 1963 (denoted by circles), compared with the distribution of recaptures in previous springs (1960-1962)

seems quite likely that these fish were also caught in the same area, since a large fleet of Dutch vessels was fishing for soles in rectangles $\mathrm{G} \& \mathrm{H}, 5 \& 6$, at that time. These fish showed no tendency to move inshore, being recaptured in about the same position as the soles caught in the first quarter of the year. None of the tagged fish was caught in the Danish coastal fishery in the spring of 1963.

If these spring recaptures were typical of the movements of this stock of fish as a whole in 1963, it would have been expected that the Danish coastal fishery would be poor; in fact, the Danish sole landings for the period April to June, covering the coastal spawning period, were only 142 tons in 1963 , having fallen to $8 \%$ of their level for 1962 of 1,754 tons (MøLler Chr rstensen, personal communication; Table 3). The Dutch spring coastal fishery was also late and very poor in 1963 (Table 3) the total catch from April to June, 22 tons, being only $14 \%$ of the catch of 152 tons made in the same period in 1962 (ANON 1963a). Similarly the small English east coast inshore sole fishery was very poor and late, few soles being caught until June-July compared with good April and May landings in the two previous years. 
The very small catches made in these coastal fisheries, which were based largely upon spawning soles, might have been accounted for by the large reduction in size of the stocks. The heavy catches of soles during the winter must have caused a considerable decrease in the potential numbers of spawners, and the mortalities due to the low water temperatures, and predation, would have reduced their numbers still fur-

Table 3

Total catch (tons) of Danish and Dutch coastal sole fisheries

\begin{tabular}{|c|c|c|c|c|}
\hline Year & March & April & May & June \\
\hline \multicolumn{5}{|c|}{ Danish coastal catch } \\
\hline $\begin{array}{l}1960 \\
1961 \\
1962 \\
1963\end{array}$ & & $\begin{array}{r}40.9 \\
528.0 \\
32.3 \\
4.9\end{array}$ & $\begin{array}{r}883.5 \\
709.5 \\
1,195.0 \\
31.2\end{array}$ & $\begin{array}{l}356.9 \\
175.5 \\
526.7 \\
105.7\end{array}$ \\
\hline \multicolumn{5}{|c|}{ Dutch coastal catch } \\
\hline $\begin{array}{l}1960 \\
1961 \\
1962 \\
1963\end{array}$ & $\begin{array}{r}1.3 \\
5.4 \\
16.0 \\
3.0\end{array}$ & $\begin{array}{r}17.7 \\
33.6 \\
25.4 \\
1.2\end{array}$ & $\begin{array}{r}30.1 \\
85.6 \\
83.0 \\
8.7\end{array}$ & $\begin{array}{l}53.4 \\
92.4 \\
43.6 \\
12.1\end{array}$ \\
\hline
\end{tabular}

Table 4

English and Dutch spring-summer landings of soles (tons) from southern North Sea. Dutch landings exclude the catch of the coastal fisheries ("Kustvisserij" in Maandstatistiek van de visserij, Anon. 1963b)

\begin{tabular}{|c|c|c|c|c|c|}
\hline Year & April & May & June & July & August \\
\hline \multicolumn{6}{|c|}{ English trawelers } \\
\hline 1960 & 52.3 & 17.2 & 15.8 & 31.3 & 34.3 \\
\hline 1961 & 21.8 & 18.1 & 31.8 & 33.1 & 38.2 \\
\hline 1962 & 95.5 & 14.7 & 12.7 & 11.9 & 23.7 \\
\hline 1963 & 625.7 & 189.8 & 29.0 & 16.6 & 24.9 \\
\hline \multicolumn{6}{|c|}{ Dutch trawelers } \\
\hline 1960 & 790.9 & 707.0 & 599.9 & 439.6 & 465.5 \\
\hline 1961 & 920.9 & $1,016.8$ & 778.6 & 607.7 & 710.1 \\
\hline 1962 & $1,275.5$ & $1,977.9$ & $1,521,8$ & $1,051.7$ & 920.1 \\
\hline 1963 & $2,217.4$ & $1,564.9$ & 726.3 & 557.2 & 442.8 \\
\hline
\end{tabular}

ther. But if this had been the only reason for the fall in the catches of the coastal fisheries, it might have been expected that catches on the offshore fishing grounds would also have fallen rapidly below the level of previous years once the water temperatures had risen again, and the surviving soles began to move inshore. However, this was not the case in the English trawl fisheries where the catches were rather greater than those for the same months in 1962, despite the fact that a decrease in catches had been expected from consideration of the probable size of the sole stocks in 1963 (Table 4). Catches in the Dutch offshore trawl fisheries did begin to fall in May, and 
by June-July were only half those of 1962; nevertheless this reduction was still small in proportion to that which occurred in the coastal fisheries. It is therefore suggested that an unusually large part of the sole stocks did not migrate inshore at all in the spring of 1963 , but probably remained in roughly those areas to which they had been displaced during the winter, as had occurred for the few English tagged soles recaptured at that time (Fig. 3).

\section{THE RELATIONSHIP OF WINTER SOLE CATCHES TO SEA TEMPERATURES}

Since the sole population of the North Sea seems to be particularly sensitive to temperature, and catches may be very high in severe winters (when part of the population may also be killed by low water temperatures), it seems likely that during less rigorous winters, although high mortalities may not occur, the soles may still be concentrated into smaller areas by cold water formation off the shallow continental coasts, and that activity may fall to a low level, increasing vulnerability to the trawl; the fish may also spend a longer time on the offshore fishing grounds. In such a case the winter catches of soles might be expected to be related to sea temperatures, at least below a certain temperature limit. Data on the English catches of North Sea sole have therefore been considered in relation to sea temperatures during the winter months.

To obtain indices of the water temperatures in the southern North Sea during different winters, the mean surface temperatures observed at three lightships, during the months of February and March in each year, have been combined to give an overall mean temperature for that winter. The lightships were the "E. R.", situated about 50 miles off the Danish coast (position $55^{\circ} 23^{\prime} \mathrm{N}, 6^{0} 57^{\prime} \mathrm{E}$ ), the "Texel", off the Dutch coast (position $53^{\circ} 01^{\prime} \mathrm{N}, 4^{\circ} 22^{\prime} \mathrm{E}$ ), and the "Smiths Knoll", off eastern England (position $52^{\circ} 43^{\prime} \mathrm{N}, 2^{\circ} 18^{\prime} \mathrm{E}$ ). All three vessels are indicated in Figure 1. These lightships were chosen because long series of regular and frequent observations were available (Cons. Perm. int. Explor. Mer. 1962), and the positions of the vessels were such that each gave representative data for different sectors of the southern North Sea and each was relatively uninfluenced by freshwater run-off from large estuaries.

Some minor adjustments had to be made to the lightship temperature means. No data were available for the "E. R." for the years 1948 and 1949, nor for February 1924 , but since the mean surface temperatures at this position are related to those at the "Vyl" lightship $\left(55^{\circ} 24^{\prime} \mathrm{N}, 07^{\circ} 33^{\prime} \mathrm{E}\right)$ for which surface temperature data were available, the temperatures for 1948, 1949 and February 1924 were re-estimated from a graph of the temperature relationship between the two vessels. There have also been. small changes in the positions of the Smiths Knoll and Texel lightships since 1921, but consideration of their surface temperature data showed that these shifts had not significantly altered the monthly mean surface temperatures.

In common with many other fisheries, the sole fishery undergoes annual fluctuations related to the recruitment of young fish (BOEREMA 1962), which makes the direct comparison of catches difficult. Furthermore, when considering a series of catch 


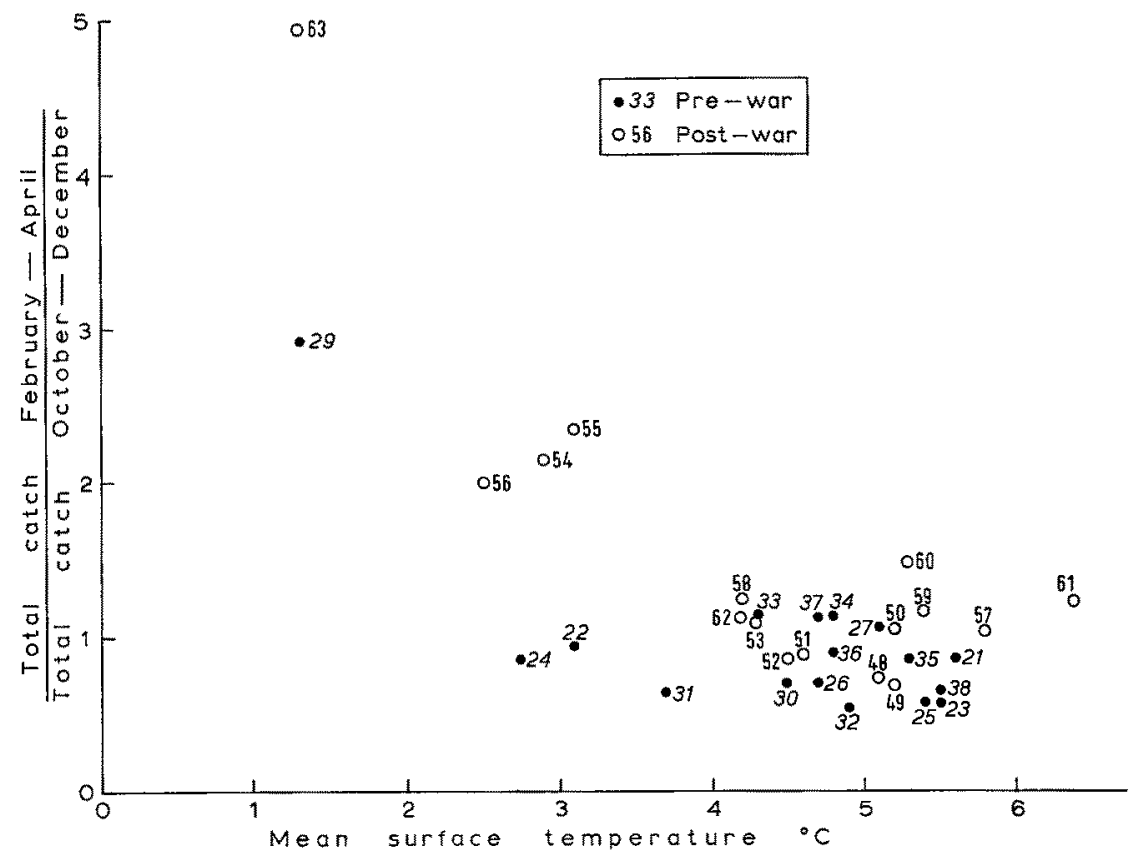

Fig. 4: The relationship between the English winter catch of soles and the mean sea temperature for February-March

Table 5

The relationship between the ratio of the winter to autumn catch of soles by English trawlers, and winter sea temperatures in the southern North Sea

\begin{tabular}{|c|c|c|c|c|c|}
\hline Year & $\begin{array}{c}\text { Mean tem- } \\
\text { perature } \\
{ }^{0} \mathrm{C} \\
\text { (surface) }\end{array}$ & $\frac{\text { Febr.-April catch }}{\text { Oct.-Dec. catch }}$ & Year & $\begin{array}{c}\text { Mean tem } \\
\text { perature } \\
0 \mathrm{C} \\
\text { (surface) }\end{array}$ & $\frac{\text { Febr--April catch }}{\text { Oct.-Dec. catch }}$ \\
\hline 1921 & 5.6 & 0.85 & 1948 & 5.1 & 0.72 \\
\hline 1922 & 3.1 & 0.93 & 1949 & 5.2 & 0.67 \\
\hline 1923 & 5.5 & 0.55 & 1950 & 5.2 & 1.05 \\
\hline 1924 & 2.8 & 0.85 & 1951 & 4.6 & 0.88 \\
\hline 1925 & 5.4 & 0.56 & 1952 & 4.5 & 0.85 \\
\hline 1926 & 4.7 & 0.73 & 1953 & 4.3 & 1.10 \\
\hline 1927 & 5.1 & 1.07 & 1954 & 2.9 & 2.16 \\
\hline 1929 & 1.3 & 2.91 & 1955 & 3.1 & 2.35 \\
\hline 1930 & 4.5 & 0.73 & 1956 & 2.5 & 2.00 \\
\hline 1931 & 3.7 & 0.63 & 1957 & 5.8 & 1.03 \\
\hline 1932 & 4.9 & 0.52 & 1958 & 4.2 & 1.24 \\
\hline 1933 & 4.3 & 1.12 & 1959 & 5.4 & 1.17 \\
\hline 1934 & 4.8 & 1.13 & 1960 & 5.3 & 1.48 \\
\hline 1935 & 5.3 & 0.85 & 1961 & 6.4 & 1.24 \\
\hline 1936 & 4.8 & 0.90 & 1962 & 4.2 & 1.12 \\
\hline 1937 & 4.7 & 1.12 & 1963 & 1.3 & 4.93 \\
\hline 1938 & 5.5 & 0.64 & & & \\
\hline
\end{tabular}


data over a long period it was necessary to make some adjustment for changes in the distribution of fishing and the effort of the fishing fleet. It was thought that the best method of eliminating these variables was to relate the total English sole catch in any winter (February to April) to the catch in the previous autumn (October to December). In any year recruitment to the fishery had been completed during the autumn and annual fluctuations could therefore be reduced by using the ratio of the autumn to winter catches. It was also considered that the fishing effort of the trawler fleet in any autumn would be the same as, or bear a fairly constant relationship to, the effort employed in the following winter (although in any winter high catches of soles might attract an increased fishing effort from vessels which would normally have pursued other species). It was possible to calculate this ratio for a number of winters from 1921 to 1963, although the data for 1928, and from 1939 to 1947, were incomplete.

The relationship of the sea temperature to the total catch of soles in February to April (winter), expressed as a ratio of the catch in October to December (autumn), is given in Table 5 and Figure 4. It is apparent that, at least for the post-war period, the catches of sole did bear some relationship to temperature, the winter catch ratio increasing when winter mean temperatures fell below about $4^{\circ} \mathrm{C}$.

In the pre-war period the relationship was by no means obvious, only the cold winter of 1929 giving a very high ratio although there were few cold winters in the pre-war period. The differences between the pre-war and post-war figures may be due to the different areas of exploitation by the fishing fleets; the English fleet now certainly moves more widely over the North Sea. Modern diesel trawlers also fish more efficiently and can continue to work under worse weather conditions than was the case before the war. Severe winters usually involve more bad weather, which would have placed greater restrictions on the pre-war trawlers. These changes may be reflected in the finding that the average ratio of winter catches to autumn catches (for mean winter temperatures above $4^{\circ} \mathrm{C}$ ) was 0.8 before 1938 , whereas in the postwar period the winter and autumn catches were the same, with a mean ratio of 1 . In fact it has really only been in recent years, since 1953, when modern motor trawlers have formed an increasingly high proportion of the fishing fleet, that the catch ratio has actually risen much above the pre-war level (to a mean value of 1.2). Again this would suggest that the modern vessels can indeed exploit the winter fisheries more efficiently than was the case with the older trawlers.

It was unfortunate that insufficient data were available to calculate the catch ratio for the very cold winter of 1946/47. However, from the data given by SIMPSON (1953) for the average catches of soles during the winter months of 1947 , it was apparent that the average catch for February to March was about twice that for October to December. Allowing for a possibly higher fishing effort being deployed in the areas of high sole catches during the winter, the winter ratio for 1947 would probably have been a little higher than 2. The temperature data for 1947 are also incomplete, but the mean February-March surface temperature would probably have been between $0^{\circ}$ and $1^{0} \mathrm{C}$ (Cons. Perm. int. Explor. Mer 1962, Vaux 1953). At this temperature the winter catch-ratio would therefore be lower than expected from the general trend of the other figures. It was considered that this low ratio was partly due to the high mortalities which occurred amongst the soles. In 1947 cooling occurred very quickly and the cold 
water masses extended rapidly outwards from the continental coasts, apparently trapping and killing many soles. In contrast, temperatures did not become so extreme and the cold waters developed more slowly in 1963; apparently this allowed time for most of the soles to move out of the coldest areas to form concentrations giving very high catches.

\section{SUMMARY}

1. Exceptionally large catches of soles are made in the North Sea during very cold winters. It was considered that these catches were due to increased vulnerability of the fish to trawling at low sea temperatures, and to the concentration of fish into smaller areas, of high density, by the cold water masses. A third contributory factor was that the soles remained on the offshore trawling grounds for a longer time in cold winters.

2. Data from fishing reports, sole catches in different regions of the southern North Sea, and the positions of recapture of tagged soles in the winter of $1962 / 63$ were used to illustrate the changes in the behaviour of this fish.

3. Although soles suffered high mortalities from low temperatures, predation, and from fishing during winter $1962 / 63$, reducing the numbers of potential spawning fish, it was suggested that the failure of the coastal spawning fisheries was also partly due to a large part of the stock failing to migrate inshore in this year.

4. It was considered that since soles appear to be particularly sensitive to low temperatures there might be a direct relationship between the winter catches of soles and the sea temperatures. This relationship was investigated and seems to hold good, at least for the post-war years since 1948.

\section{ACKNOWLEDGMENTS}

I wish to record my thanks to Dr. Karl Andersen, Director of the Danske Meteorologiske Institut, for making available unpublished surface temperature observations at the E. R. Lightship for 1961/63, and to Dr. J. A. van Durjnen Montrjn of the Koninklijk Nederlands Meteorologisch Instituut, for making available similar data for the Texel Lightship. I am most grateful to Mr. Jørgen Møller Christensen for sending me data on the Danish coastal sole fishery. Mr. T. Wilirams and Mr. J. A. Gulland kindly allowed me to make use of the recapture data for tagged soles. I am also pleased to thank Dr. I. K. Boerema, Mr. D. J. Ellett, Dr. C. Gilis and Dr. H. Kruuk for permission to quote their papers.

\section{LITERATURE CITED}

Anon., 1963a. Fish stock record 1962. Min. of Ag., Fish and Food, and Dept. of Ag. Fish. for Scotland, 7-9.

- 1963b. Maandstatistiek van de visserij. Central Bureat voor de statistiek. Uitgeversmaatschappij W. de Haan N. V, Zeist.

Boerema, L. K., 1962. Some notes on the sole fishery. I. C. E. S. Near Northern Seas Committee No. 93, 1-7. 
Boerema, L. K., 1964. Some effects of diurnal variation in the catches upon estimates of abundance of plaice and sole. Rapp. Cons. Explor. Mer 155 (In press).

- \& Stam, A. B., 1952. A preliminary note on the sole in the Dutch coastal area. I. C. E.S. Nortb Sea Committee, 1-3.

Conseil Permanent Internationale Pour L'exrloration de la Mer, Service HydroGRAPHIQUE, 1962. Mean monthly temperature and salinity of the surface of the North Sea and adjacent waters, from 1905 to 1954.

ElLETT, D. J., 1963. Surface temperatures in the southern North Sea, January-March 1963. I. C. E.S. Hydrographical Committee Paper No. 115, 1-7.

GiLIs, C., 1963. Note préliminaire sur les pêches abondantes de soles réalisées par les pêcheurs belges dans le sud de la Mer du Nord (IVc) au cours de l'hiver 1962-1963. I.C.E.S. Near Nortbern Seas Committee Paper No. 30, 1-3.

KRuUk, H., 1963. Diurnal periodicity in the activity of the common sole, Solea vulgaris Quensel. Neth. J. Sea Res. 2, 1-28.

LumbY, J. R. \& AtKinson, G. T., 1929. On the unusual mortality amongst fish during March and April, 1929, in the North Sea. J. Cons. 4, 309-332.

Møiler Christensen, J., 1962. Migration. In: Report of the working group on Sole. I.C.E.S. Near Northern Seas Committee Paper No. 92, 28-29.

Report of the Working Group on Sole, 1962. I. C.E.S. Near Northern Seas Committee Paper No. 92, 16-29.

Simpson, A. C., 1953. Some observations on the mortality of fish and the distribution of plankton in the southern North Sea during the cold winter, 1946-1957. J. Cons. 19, 150-177.

VAux, D., 1953. Hydrographical conditions in the southern North Sea during the cold winter of 1946-1947. J. Cons. 19, 127-149.

Wood, W., 1911. North Sea fishers and fighters. Paul, Trench, Trübner \& Co., London, 39-40.

Woodhead, P. M. J., 1964a. Diurnal changes in trawl catches of fish. Rapp. Cons. Explor. Mer 155 (In press).

- 1964b. A change in the normal diurnal pattern of capture of soles during the severe winter of 1963. Rapp. Cons. Explor. Mer 155 (In press).

- 1964c. The death of North Sea fish during the winter of 1962-63, particularly with reference to the sole, Solea vulgaris. Helgol. Wiss. Meeresunters. 10 (In press.).

\section{Discussion following the paper by WOODHEAD}

Fonds: Is there a relation between severe winter mortality and the occurrence of young sole (Solea vulgaris) spawned this year during the following year?

WOODHEAD: It is a feature of very cold winters that despite the mortalities occurring in the adult sole stocks, these depleted stocks often give rise to very strong year-classes. This was so in 1947 and also in 1929 and 1924. (One of the latter was, however, much better than the other. I think that Professor Bückmann could tell us which.) We don't really know why this happens. It will be most interesting if there has also been a strong year-class this year.

BüCKMANN, A.: 1922 war ein reicher Jahrgang nach einem kalten Winter. 1929 war nicht ausgesprochen schlecht. Es ist zweifelhaft, ob die Zungen der ersten Lebensjahre, die an der Festlandsküste im Wattenmeer im Boden eingegraben überwintern, in gleichem Maße in kalten Wintern zugrunde gehen wie die älteren Fische im offenen Meer. 1929 gab es Anzeichen, daß dies nicht der Fall wäre.

WOODHEAD: Certainly for small soles that were actually in the sea during the winter the mortalities were very high. Some trawlers reported very big catches of very small soles, which filled their nets. Some were dead, though most of them were torpid. But quite apart from the trawl catches, there seems to have been a very high mortality in small soles - fish of 3 to 6 inches long - through predation. Time and again we had reports of cod being captured, and 
their stomachs were absolutely full of small soles. This again was probably due to a dange in behaviour and vulnerability. Apparently the soles were not digging into the sand as they normally do, or perhaps were not quite covered by sand, and they were being picked up by the predatory fish, the large cod, with relative ease. In normal winters it is unusual to catch cod with their stomachs absolutely full of small soles, but this occurred again in the cold winters of 1947. I do not know that there is any d i r e $\mathrm{ct}$ connection between cold winters and good year class survival. We have little evidence for this, although it seems to follow.

KotThaus: Trotz der starken Verluste des Solea vulgaris-Bestandes durch den Eiswinter 1946/47 wurde im gleichen Jahr ein ungewöhnlich reicher Nachwuchsjahrgang erzeugt. Bei einer Reihe von anderen Fischen, so vor allem bei der Scholle, Pleuronectes platessa, war der Jahrgang 1947 ungewöhnlich volksstark. Vielleicht erklärt sich daraus, daß die Laichzeit durch die ungewöhnliche Kälte weit hinausgezögert wurde, wodurch die nun spärer geborene Brut in die Hauptplanktonblïte geriet und dort bessere Ernährungsbedingungen und Oberlebensmöglichkeiten fand.

WOODHEAD: Mr. R. J. H. BEverTon of our laboratory carried out extensive tow-net surveys over the Southern Bight spawning grounds of the plaice this winter. He found unprecedented numbers of plaice eggs in his nets. Apparently the very low temperatures were retarding the normal rate of development so that the eggs were not going through to hatch, but accumulating as the plaice continued spawning. It will be interesting to see what the year-class survival is like, since all the eggs finally went through to hatch out at much the same time.

BARNES: Is there any evidence that low temperatures show some of the more subtle effects on the eggs and subsequent year classes as revealed by Professor KINNE's experiments with respect to salinity?

WOODHEAD: There may very well be effects of this nature. Thus we find marks on the scales or the otoliths of fish that have been reared under different temperature conditions. These are useful as tags or labels, but we don't yet know fundamentally what has happened.

BARNEs: Is the high egg density possibly due to aggregation of spawners?

WoODHEAD: There was probably some degree of concentration of the spawning plaice, the distribution of the eggs being a little nearer the English coast than usual as the adults presumably avoided the cold continental shallows. But this concentration probably wouldn't do more than double or treble the number of eggs at any position, whereas the eggs accumulated to much higher concentrations than this. The surveys actually cover the entire spawning area to get the to $t$ a l number of eggs spawned in any winter.

BARNES: Is it not curious that abnormal years produce more fish which would be expected to be "better" adjusted?

WOODHEAD: The death of the adults in the winter and the survival of a year-class are not directly connected since the sole is a summer-spawner. The low temperatures of the winter have therefore passed when the larvae hatch out. There may be some indirect connections between cold winters and plankton production, etc., in early summer which allow a good year-class survival, but I think that the answer at present is that we don't really know. Certainly the connection with the cold winters is not direct.

AUrich: Ergänzend zu den Ausführungen von Herrn WOODHEAD und zu den Referaten über den Einfluß des kalten Winters auf Plankton und Bodenfauna möchte ich einige vorläufige Ergebnisse unserer Untersuchungen über das Plankton im Seegebiet um Helgoland während des Frühjahres 1963 mitteilen. In Tabelle D1 sind die Maximalwerte für die Häufigkeit der Eier einiger Fische in den Jahren 1950 bis 1954 denen von 1963 gegenübergestellt (s. Tabelle D 1). Bei Sprott, Wittling und Seezunge (hier sind die Werte nur bedingt vergleichbar, da 1963 das Laichgebiet der Seezunge lediglich am Rande erfaßt wurde) ist die Häufigkeit der Eier von etwa der gleichen Größenordnung wie in den früheren Jahren. Der hohe Wert für die Kliesche im Mai 1963 ist wohl durch eine Verzögerung des Laichens bedingt. Die in der südlichen Nordsee einheimischen, südlich-borealen Arten lassen also keinen Einfluß des kalten Winters 
Tabelle D 1

Maximale Häufgkeit der Eier (unter $1 \mathrm{~m}^{2}$ Meeresoberfläche) westlich und südlich Helgoland

\begin{tabular}{|c|c|c|c|c|c|c|}
\hline & \multicolumn{2}{|c|}{ Mai/Juni } & \multirow[b]{2}{*}{$\begin{array}{c}\text { Pleuro- } \\
\text { nectes } \\
\text { limanda } \\
\text { (Kliesche) }\end{array}$} & \multirow[b]{2}{*}{$\begin{array}{l}\text { Solea } \\
\text { vulgaris } \\
\text { (Seezunge) }\end{array}$} & Juli & \multirow[b]{2}{*}{$\begin{array}{c}\text { Trachurus } \\
\text { trachurus } \\
\text { (Bastard- } \\
\text { makrele) }\end{array}$} \\
\hline & $\begin{array}{l}\text { Clupea } \\
\text { sprattus } \\
\text { (Sprott) }\end{array}$ & $\begin{array}{l}\text { Gadus } \\
\text { merlangus } \\
\text { (Wittling) }\end{array}$ & & & $\begin{array}{c}\text { E. encrassi- } \\
\text { cholus } \\
\text { (Sardelle) }\end{array}$ & \\
\hline 1950 & 900 & 12 & 25 & 36 & 800 & 130 \\
\hline 1951 & 100 & 9 & 25 & 21 & 530 & 150 \\
\hline 1952 & & & & & 750 & 100 \\
\hline 1953 & 300 & 27 & 230 & 40 & 600 & 200 \\
\hline 1954 & 850 & 15 & 100 & 70 & 200 & 300 \\
\hline 1963 & 900 & 21 & 800 & 12 & 9 & 40 \\
\hline
\end{tabular}

erkennen. Dagegen macht sich ein solcher bei den mediterran-atlantischen Fischen bemerkbar. Bei ihnen hat die Brutdichte 1963 deutlich abgenommen. Das gleiche gilt für die anderen Sommerlaicher (Callionymus, Solea lutea, Arnoglossus, Trigla, Scomber), von denen 1963 keine oder nur wenige vereinzelte Eier und Larven beobachtet wurden. - Nach den Ausführungen der Herren Crisp und Zregelmerer hat die Bodenfauna zum Teil stark unter der Kälteperiode 1962/63 gelitten. Für Lanice conchilega wurde eine fast 100prozentige Vernichtung der Bestände an der englischen und deutschen Küste angegeben. Um so überraschendex ist es, daß 1963 die Häufigkeit der Larven keine entsprechende Abnahme zeigt (Tab. D 2).

Tabelle D 2

Häufigkeit der Larven des Polychaeten Lanice conchilega (unter $1 \mathrm{~m}^{2}$ Oberfläche) im Gebiet südlich und ostwärts Helgoland

\begin{tabular}{|llrlll|}
\hline 1950 & Juni & $4500-25000$ & Juli & $1500-6000$ \\
1952 & Juni & $3000-13500$ & Juli & $1350-15000$ \\
1953 & April & $600-1500$ & Juni/Juli & $1800-18000$ \\
1954 & Mai/Juni & $300-1700$ & Juli & $330-$ & 650 \\
\hline 1963 & Mai & $300-400$ & Juli/August & $900-13000$ \\
\hline
\end{tabular}

Im Mai 1963 sind zwar die Werte beachtlich niedriger als in den Jahren 1950 bis 1954, doch ist dies teils auf den früheren Zeitpunkt, teils, wie bei der Kliesche, auf eine Verzögerung des Laichens zurückzuführen. Im Sommer aber wird eine Häufigkeit wie in den vorhergehenden Jahren erreicht. 